\title{
The stability of blood Eosinophils in chronic obstructive pulmonary disease
}

\author{
Gabriella H. Long ${ }^{1 *}\left(\mathbb{D}\right.$, Thomas Southworth ${ }^{1,2}$, Umme Kolsum ${ }^{1,2}$, Gavin C. Donaldson ${ }^{3}$, Jadwiga A. Wedzicha ${ }^{3}$, \\ Christopher E. Brightling ${ }^{4}$ and Dave Singh $h^{1,2}$
}

\begin{abstract}
Blood eosinophils are a predictive biomarker of inhaled corticosteroid response in chronic obstructive pulmonary disease (COPD). We investigated blood eosinophil stability over 1 year using the Global Initiative for Chronic Obstructive Lung Disease (GOLD) 2019 thresholds of $<100,100-<300$ and $\geq 300$ eosinophils/ML in 225 patients from the COPDMAP cohort. Blood eosinophils showed good stability (rho: $0.71, p<0.001$, ICC 0.84 ), and $69.3 \%$ of patients remained in the same eosinophil category at 1 year. $85.3 \%$ of patients with eosinophils $<100$ cells/ $\mathrm{LL}$ had stable counts. The majority of blood eosinophil counts remain stable over 1 year using the GOLD 2019 thresholds.
\end{abstract}

Keywords: COPD, Eosinophil, Airway inflammation

\section{Introduction}

Randomised controlled trials have shown a relationship between blood eosinophil counts and the effects of inhaled corticosteroid (ICS) on exacerbations in chronic obstructive pulmonary disease $(\mathrm{COPD})[1-3]$. Data modelling suggests that ICS effects are observable at $>100$ cells $/ \mu \mathrm{L}$, with the greatest effects at $\geq 300$ cells $/ \mu \mathrm{L}$ [4]. The Global Initiative for Chronic Obstructive Lung Disease (GOLD) 2019 report recommends $<100$ and $\geq 300$ eosinophils/ $\mu \mathrm{L}$ thresholds to identify patients who are least and most likely, respectively, to benefit from ICS treatment [3].

The stability of blood eosinophil counts over time is an issue that is relevant for the use of this biomarker in COPD patients. Changes in blood eosinophil counts that result in movement across the thresholds recommended by GOLD may influence pharmacological treatment decisions. Greater variability for repeated blood eosinophil counts has been reported at higher eosinophil levels [5-7], but the stability of eosinophil counts has not been assessed using current GOLD recommended thresholds. We have analysed the stability of blood eosinophil counts over 1 year in the COPDMAP observational cohort study (www.copdmap.org; study

\footnotetext{
* Correspondence: gabriella.long@postgrad.manchester.ac.uk

${ }^{1}$ Division of Infection, Immunity and Respiratory Medicine, School of

Biological Sciences, Faculty of Biology, Medicine and Health, Manchester

Academic Health Science Centre, The University of Manchester, Manchester,

UK

Full list of author information is available at the end of the article
}

design described previously [8]) using the GOLD 2019 thresholds.

\section{Methods}

COPD patients with two blood eosinophil measurements taken at baseline and 12 months apart during stable state were included $(n=225)$ to determine within-subject variability over time. Patients with a previous asthma history or requiring maintenance oral corticosteroid therapy were excluded from this analysis. All patients provided written informed consent and local ethical approvals were obtained (11/L0/1630;10/H/1003/108; 07/H0406/157). Additional methods are in the online supplement (Additional file 1). Patients were subdivided into 3 groups using the baseline blood eosinophil count; $<100,100-<300$ or $\geq 300$ cells/ $\mu \mathrm{L}$. Data were analysed using spearman's rank test (Prism 7.0, GraphPad, USA), intraclass correlation coefficient (ICC) of log-transformed data, analysis of variance (ANOVA), linear regression, Bland-Altman and repeatability coefficient analysis (RCA) calculated as 1.96 multiplied by $\sqrt{2}$ times the within-subject standard deviation (SPSS 22.0, IBM, Armonk, USA) [9]. ICC values are interpreted as excellent $(>0.75)$, fair to good $(0.40-0.75)$, or poor $(<$ $0.40)[9] . P<0.05$ was considered statistically significant.

\section{Results}

Patients had a mean (SD) age of 69.8 (8.4) years, forced expiratory volume in $1 \mathrm{~s}\left(\mathrm{FEV}_{1}\right) 55.9 \%$ (18.2\%) predicted, 
COPD assessment test (CAT) score 16.9 (7.5), and 1.6 (2.1) exacerbations per year; $67.1 \%$ were male, $29.3 \%$ were current smokers and $80.4 \%$ were on ICS therapy. The number of patients with blood eosinophils $<100$, $100-<300$ and $\geq 300$ cells $/ \mu \mathrm{L}$ were 38 (16.9\%), 139 $(61.8 \%)$ and $48(21.3 \%)$ respectively; clinical characteristics of these groups were similar.

There was a significant correlation between blood eosinophil counts at baseline and 12 months $(n=225)$; rho $=0.71, p<0.001$. The ICC value was 0.84 , indicating excellent repeatability. Bland-Altman regression analysis showed lowest and greatest variability at $<100$ eosinophils $/ \mu \mathrm{L}$ and $\geq 300$ eosinophils $/ \mu \mathrm{L}$ at baseline respectively (linear regression $\mathrm{p}<0.001$ ). Repeatability coefficients for blood eosinophils $<100,100-<300$, and $\geq 300$ cells $/ \mu \mathrm{L}$ showed that $95 \%$ of measurements at 12 months were within 88,175 and 429 cells/ $\mu \mathrm{L}$ of the baseline value, respectively [Fig. 1]. 69.3\% $(n=156)$ of patients had blood eosinophils that remained within the same category over 12 months; $47.4,77.7$ and $62.5 \%$ of patients remained stable at $<100,100-<300$ cells $/ \mu \mathrm{L}$, and $\geq 300$ cells $/ \mu \mathrm{L}$, respectively [Fig. 1]. Of those patients with blood eosinophils $<100$ or $\geq 300$ cells/ $\mu \mathrm{L}$ who changed group, the majority (36/38 patients) moved to the adjacent group.

Baseline blood eosinophil counts were similar in patients who remained $<100$ cells $/ \mu \mathrm{L}$ compared to those who changed group [Fig. 2]. Blood eosinophil counts in patients who remained in the $100-<300$ cells $/ \mu \mathrm{L}$ group were lower compared to those who changed to $\geq 300$ cells $/ \mu \mathrm{L}$ (medians 190 vs 240 cells $/ \mu \mathrm{L}$, respectively, $p=$ 0.0053), while the lowest counts were observed in those who moved to $<100$ cells $/ \mu \mathrm{L}$ (median 140 cells $/ \mu \mathrm{L}, p=$ 0.12 for comparison versus patients who remained in the $100-<300$ cells $/ \mu \mathrm{L}$ group). For patients with blood eosinophils $\geq 300$ cells $/ \mu \mathrm{L}$, those that moved below 300 cells $/ \mu \mathrm{L}$ at 12 months had a lower baseline measurement compared to those who remained $\geq 300$ cells $/ \mu \mathrm{L}$ (median 360 vs 420 , respectively, $p=0.024$ ). Only 3 patients (out of 225) changed ICS use within the 12-month observation period; these patients were commenced on ICS treatment, and none dropped to a lower eosinophil group.

There were 99 patients who experienced $\geq 1$ exacerbation within the 12 month period between stable state blood eosinophil measurements. The correlation between repeated blood eosinophil measurements was similar in patients with $\geq 1$ exacerbation (rho $=0.73, p<0.001)$ and those with no exacerbations $(n=126$; rho $=0.71, p<$ 0.001 ). For patients with $\geq 1$ exacerbation, $72.7 \%$ remained within the same group, whilst $66.7 \%$ of those with no exacerbations were stable over 12 months. Similar results were obtained when patients with exacerbations were divided into those with 1 exacerbation within the 12-month period ( $n=64$; blood eosinophils were stable in $71.9 \%$ ) and those with $\geq 2$ exacerbations $(n=35$; blood eosinophils were stable in $74.3 \%$ ).

Subgroup analysis of blood eosinophil stability according to ICS use showed similar results in those using ICS $(n=181 ;$ rho $=0.58, p<0.001)$ and those not using ICS $(n=44 ;$ rho $=0.47, p=0.001)$. For patients using on ICS, $70.2 \%$ had blood eosinophil counts that remained in the same group over 12 months, while this was $65.9 \%$ for those not using ICS.

\section{Discussion}

The main findings were that (1) blood eosinophil stability over 12-months was excellent when analysed by ICC (0.84), (2) regression analysis showed greater variability at higher eosinophil counts (3) $69.3 \%$ of patients remained

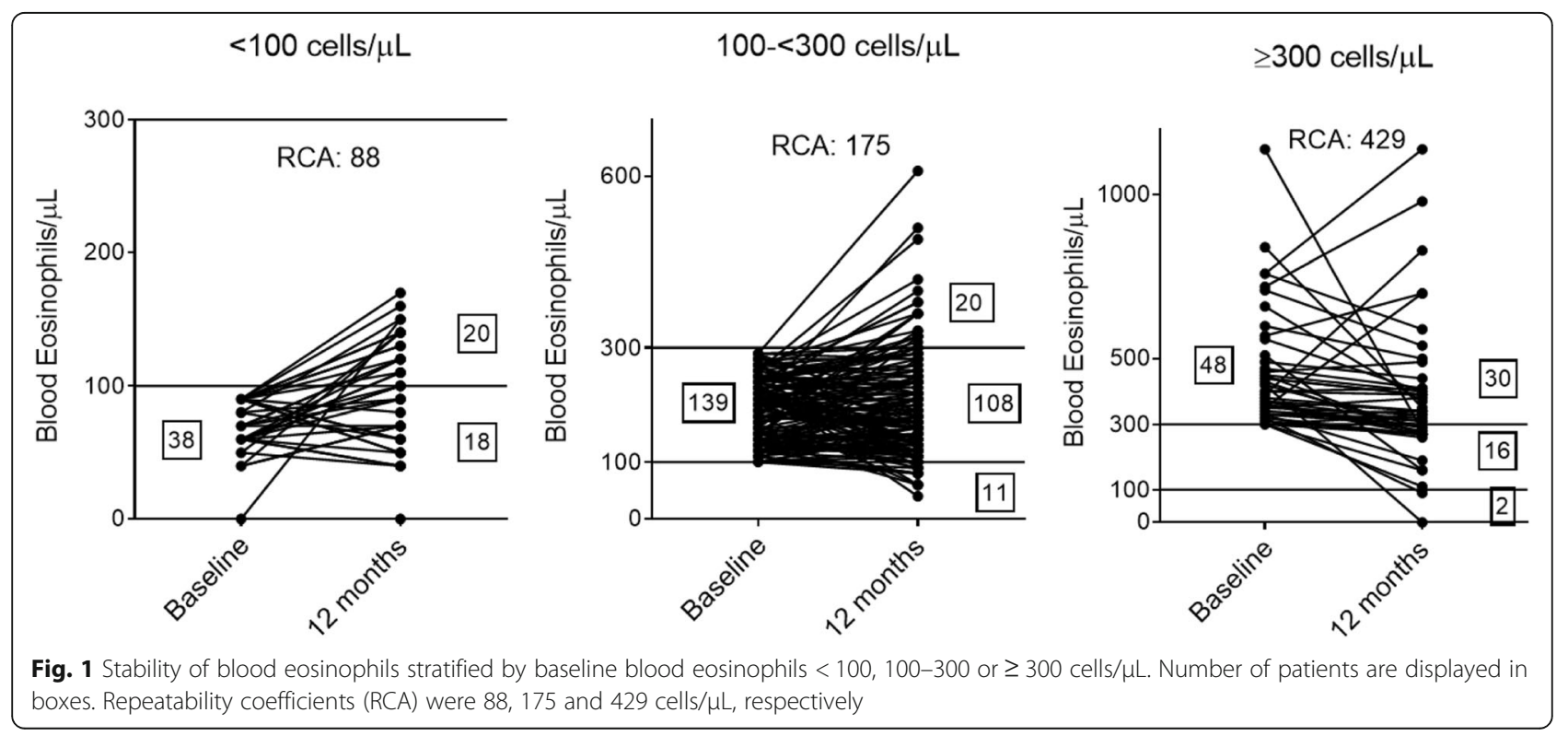




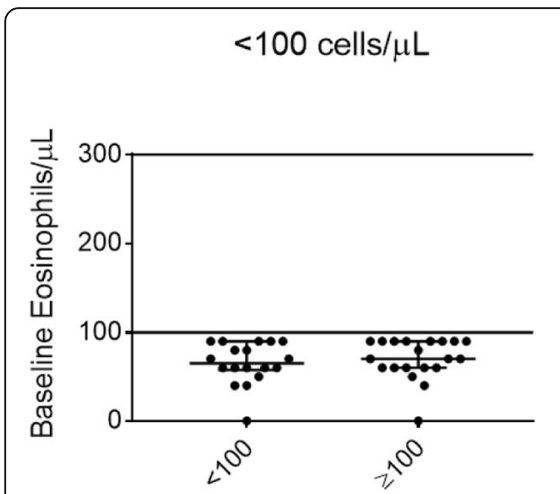

12 month Eosinophils/ $\mu \mathrm{L}$

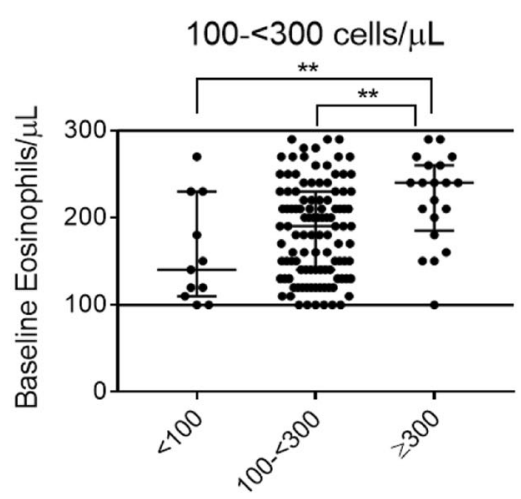

12 month Eosinophils/ $\mu \mathrm{L}$

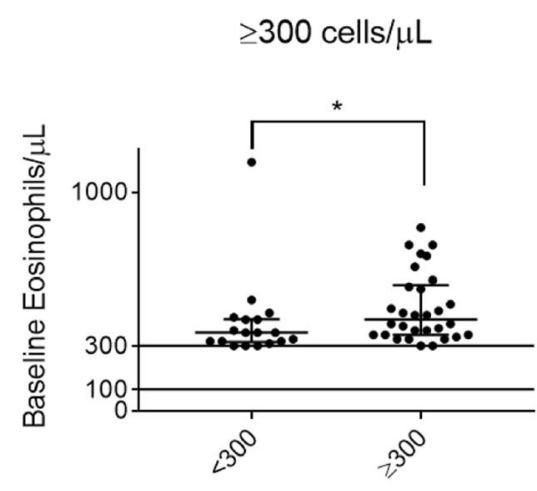

12 month Eosinophils/ $\mathrm{LL}$

Fig. 2 Comparison of baseline blood eosinophil counts in those who remained versus changed 12-month blood eosinophil group. Graphs stratified by baseline groups $<100,100-<300$ or $\geq 300$ cells/ML, respectively. Error bars represent median and IQR. ${ }^{*}=p<0.05 .{ }^{* *}=p<0.01$

stable within the same category (4) movement between groups was more likely when baseline values were closer to a threshold. The main clinical usefulness of these findings is to demonstrate that the majority of COPD patients remain within the same blood eosinophil category (defined by GOLD) after 1 year. This provides reassurance regarding treatment decisions using this biomarker.

GOLD 2020 now states that the thresholds of $<100$ cells $/ \mu \mathrm{L}$ and $>300$ cells $/ \mu \mathrm{L}$ are "estimates, rather than precise cut-off values" with respect to the prediction of ICS effects [10]. This concept is important when considering movement across these thresholds after repeat testing, which occurred in approximately $30 \%$ of patients in this study. The continuous nature of the blood eosinophil count - ICS response relationship means that small numerical changes after a repeat test are unlikely to be associated with a significant change in ICS responsiveness. We observed that movement across a threshold was more likely for baseline measurements that were closer to the threshold; this appears to be natural measurement variation across a threshold rather than a significant change in the pathophysiology of an individual. We suggest that these small numerical movements across a threshold should not change the original clinical interpretation based on the baseline blood eosinophil count. Similarly, 1-year stability in COPD patients $(n=27,557)$ at 12 -months has been reported (ICC $=0.7$ ), with lower blood eosinophil reliability for measurements close to thresholds [11]. Average blood eosinophil counts for repeated measurements in clinical practice may overcome this variability [11].

Previous studies have shown similar ICC values for blood eosinophil counts $[6,7,11]$. E.g. Southworth et al. studied a smaller COPD cohort $(n=82)$ using thresholds $<150,150-<300$ and $\geq 300$ cells $/ \mu \mathrm{L} ; \mathrm{ICC}=0.89$ and 0.87 at 6 months and 2 years respectively, with 71 and $64 \%$ respectively of patients remaining within the same category [6]. Greulich et al. $(n=334)$ similarly found those with blood eosinophils $<150$ cells $/ \mu \mathrm{L}$ had greater stability over 18 months [12]. The importance of our results is that we have used the thresholds defined by GOLD. Furthermore, we observed that 192/225 (85.3\%) patients had eosinophil measurements that were stable using the 100 eosinophils/ $\mu \mathrm{L}$ threshold. Similarly, Southworth et al. reported 91 and $85 \%$ stability at 6 months and $>2$ years respectively using 100 eosinophils/ $\mu \mathrm{L}$ [6]. Using only the lower eosinophil threshold in the GOLD report therefore appears to provide stable results in the majority of cases.

More patients moved across the threshold from the < 100 cells $/ \mu \mathrm{L}$ group $(52.6 \%)$ at baseline compared to the $\geq 300$ cells/ $\mu \mathrm{L}$ group $(37.5 \%)$. Most of this variation from the $<100$ cells $/ \mu \mathrm{L}$ group $(n=36 / 38)$ resulted in movement to the adjacent group $(100-<300$ cells $/ \mu \mathrm{L})$. The discordance between variability of absolute eosinophil numbers and movement across a threshold can be attributed to the wider measurement range at $\geq 300$ cells/ $\mu \mathrm{L}$ e.g. $20 \%(6 / 30)$ of individuals who remained $\geq 300$ cells $/ \mu \mathrm{L}$ had an absolute change $\geq 200$ cells $/ \mu \mathrm{L}$, while all patients $(n=18)$ who remained $<100$ cells $/ \mu \mathrm{L}$ changed $<50$ cells $/ \mu \mathrm{L}$.

Increased blood eosinophil counts in a subset of COPD patients has been demonstrated even when individuals with asthma or allergy are excluded [13]. The mechanism causing higher blood eosinophil counts in a subset of COPD patients is unclear. Blood eosinophils can be raised in the context of parasitic infections, but this was unlikely to be the cause in this UK based cohort study [14].

There was a high percentage of ICS use in our study population $(80.4 \%)$, likely due to patients being recruited across 3 hospital based research centres rather than primary care. It would be interesting to see similar data in patients in primary care, with lower exacerbation risk and ICS use. Our data had a 1 year follow up, and future analyses could extend stability analysis to longer time periods. 
In conclusion, approximately $70 \%$ of blood eosinophil measurements remained in the same category over 1 year using the GOLD 2019 thresholds. Small numerical changes may cause movement across a threshold.

\section{Supplementary information}

Supplementary information accompanies this paper at https://doi.org/10. 1186/s12931-020-1279-4.

Additional file 1. Additional Methods.

\section{Abbreviations}

ANOVA: Analysis of Variance; CAT: COPD assessment test; COPD: Chronic obstructive pulmonary disease; $\mathrm{FEV}_{1}$ : Forced expiratory volume in $1 \mathrm{~s}$; GOLD: Global Initiative for Chronic Obstructive Lung Disease; ICC: Interclass correlation coefficient; ICS: Inhaled corticosteroids; RCA: Repeatability coefficient analysis

\section{Authors' contributions}

DS was responsible for the concept and design of the study. GL analysed the data and DS oversaw all analyses. GL and DS were responsible for data interpretation and drafting the manuscript. TS, UK, GD, CEB, JW revised the manuscript critically for intellectual content. All authors have approved the final version to be published and are jointly accountable for all aspects of the work.

\section{Funding}

This study was funded by the MRC (United Kingdom). DS is supported by the NIHR Manchester BRC.

\section{Availability of data and materials}

All data generated or analysed during this study are included in this published article [and its supplementary information files].

\section{Ethics approval and consent to participate}

The COPDMAP prospective observational cohort study (www.copdmap.org) recruited patients from 3 sites (Manchester, Leicester and London). The study was approved by local Research Ethics committees at each site (11/L0/1630; 10/H/1003/108; 07/H0406/157). All participants provided written informed consent prior to recruitment.

\section{Consent for publication}

Not applicable.

\section{Competing interests}

GL, TS and UK have nothing to disclose. GD reports personal fees from Micom Ltd., personal fees from Astra-Zeneca, outside the submitted work. CB reports grants from MRC, grants from NIHR, during the conduct of the study; grants and personal fees from AZ/Medlmmune, from GSK, grants and personal fees from Chiesi, grants and personal fees from Novartis, personal fees from Sanofi, personal fees from Regeneron, grants and personal fees from Bl, grants and personal fees from 4DPharma, grants and personal fees from Mologic, grants from Merck, from TEVA, outside the submitted work. JW reports grants from GSK, grants from Johnson and Johnson, other from Novartis, other from Boehringer Ingelheim, other from Astra Zeneca, other from GSK, grants from GSK, grants from Astra Zeneca, grants from Boehringer Ingelheim, grants from Novartis, outside the submitted work. DS reports personal fees from AstraZeneca, personal fees from Boehringer Ingelheim, personal fees from Chiesi, personal fees from Cipla, personal fees from Genentech, personal fees from GlaxoSmithKline, personal fees from Glenmark, personal fees from Menarini, personal fees from Mundipharma, personal fees from Novartis, personal fees from Peptinnovate, personal fees from Pfizer, personal fees from Pulmatrix, personal fees from Theravance, personal fees from Verona, outside the submitted work.

\section{Author details}

${ }^{1}$ Division of Infection, Immunity and Respiratory Medicine, School of Biological Sciences, Faculty of Biology, Medicine and Health, Manchester
Academic Health Science Centre, The University of Manchester, Manchester, UK. ${ }^{2}$ Medicines Evaluation Unit, Manchester University NHS Foundation Trust, Manchester, UK. ${ }^{3}$ National Heart and Lung Institute, Imperial College London, London, UK. ${ }^{4}$ Institute for Lung Health, University of Leicester, Leicester, UK.

Received: 26 August 2019 Accepted: 5 January 2020

Published online: 10 January 2020

\section{References}

1. Siddiqui SH, Guasconi A, Vestbo J, Jones P, Agusti A, Paggiaro P, Wedzicha JA, Singh D. Blood Eosinophils: a biomarker of response to Extrafine Beclomethasone/Formoterol in chronic obstructive pulmonary disease. Am J Respir Crit Care Med. 2015;192(4):523-5.

2. Lipson DA, Barnhart F, Brealey N, Brooks J, Criner GJ, Day NC, et al. Oncedaily single-inhaler triple versus dual therapy in patients with COPD. N Engl J Med. 2018;378(18):1671-80

3. Singh D, Agusti A, Anzueto A, Barnes PJ, Bourbeau J, Celli BR, et al. Global Strategy for the Diagnosis, Management, and Prevention of Chronic Obstructive Lung Disease: The GOLD Science Committee Report 2019. Eur Respir J. 2019 Mar 7. pii: 1900164. doi: https://doi.org/10.1183/13993003. 00164-2019.

4. Bafadhel M, Peterson S, De Blas MA, Calverley PM, Rennard SI, Richter K, et al. Predictors of exacerbation risk and response to budesonide in patients with chronic obstructive pulmonary disease: a post-hoc analysis of three randomised trials. Lancet Respir Med. 2018;6(2):117-26.

5. Bafadhel M, Pavord ID, Russell REK. Eosinophils in COPD: just another biomarker? Lancet Respir Med. 2017;5(9):747-59.

6. Southworth $T$, Beech G, Foden P, Kolsum U, Singh D. The reproducibility of COPD blood eosinophil counts. Eur Respir J. 2018;52(1):1800427.

7. Oshagbemi OA, Burden AM, Braeken DCW, Henskens Y, Wouters EFM, Driessen JHM, et al. Stability of blood Eosinophils in patients with chronic obstructive pulmonary disease and in control subjects, and the impact of sex, age, smoking, and baseline counts. Am J Respir Crit Care Med. 2017; 195(10):1402-4.

8. Kolsum U, Donaldson GC, Singh R, Barker BL, Gupta V, George L, et al. Blood and sputum eosinophils in COPD; relationship with bacterial load. Respir Res. 2017;18(1):88.

9. Martin Bland J, Altman D. Statistical methods for assessing agreement between two methods of clinical measurement. Lancet. 1986;327(8476):307-10.

10. Global Initiative for Chronic Obstructive Lung Disease. Global Strategy for the Diagnosis, Management, and Prevention of Chronic Obstructive Pulmonary Disease (2020 Report). Available at URL: www.goldcopd.org. Published in Fontana, WI, USA.

11. Landis SH, Suruki R, Hilton E, Compton C, Galwey NW. Stability of blood eosinophil count in patients with COPD in the UK clinical practice research Datalink. COPD. 2017;14(4):382-8.

12. Greulich T, Mager S, Lucke T, Koczulla AR, Bals R, Fähndrich S, et al. Longitudinal stability of blood eosinophil count strata in the COPD COSYCONET cohort. Int J Chron Obstruct Pulmon Dis. 2018;13:2999-3002.

13. Singh D, Kolsum U, Brightling CE, Locantore N, Agusti A, Tal-Singer R. Eosinophilic inflammation in COPD: prevalence and clinical characteristics. Eur Respir J. 2014;44(6):1697 LP-1700.

14. Ramirez GA, Yacoub M-R, Ripa M, Mannina D, Cariddi A, Saporiti N, et al. Eosinophils from physiology to disease: a comprehensive review. Biomed Res Int. 2018;9095275.

\section{Publisher's Note}

Springer Nature remains neutral with regard to jurisdictional claims in published maps and institutional affiliations. 